\title{
The effect of exercise on the levels of circulating leptin in hyperlipidemic patients
}

\author{
Ibraheem M. El-Akkary*, Mohamed El-Ghazali*, Awatef M. El- \\ Sharkawi, Bothina F. Mohamed, Usama S. El-Bassiuni \\ Clinical Physiology* and Applied Medical Biochemistry Departements, \\ Medical Research institute, Alexandria University, Egypt
}

\begin{abstract}
ABSRACT
This study examined the acute (single bout of exercise) and chronic (exercise training) effects of exercise on plasma lipid levels in relation to concomittant changes in plasma leptin concentrations. Fourty sedentary adult subjects were categorized into 4 groups, ten in each :lean normolipidemic control, obese normolipidemic, lean hyperlipidemic and obese hyperlipidemic groups. Leptin levels were measured by ELISA method while plasma lipids including total cholestrol (TC), triglycerides (TG), high density lipoprotein-cholestrol (HDL-C), low density lipoprotein-cholestrol ( $L D L-C)$, and very low density lipoprotein-cho;estrol (VLDL-C) were measured by conventional colorimetric methods. These measurements were performed before and after acute and chronic exercise. Exercise training was a high intensity aerobic exercise performed on cycle ergometer at the level of $85 \%$ of maximal predicted heart rate, twice weekly for 12 weeks. Plasma leptin concentrations were significantly higher in normolipidemic $(P<0.001)$ and hyperlipidemic $(P<0.01)$ obese groups and hyperlipidemic $(P<0.01)$ non obese group compared to controls. However, there were no significant correlations between basal serum leptin levels and any of basal serum lipid profile parameters in all studied groups. No significant changes in lipid parameters or leptin concentrations after single bout of exercise. In turn, exercise training induced significant favorable reduction in TC, TG, LDL-C and VLDL-C and increase of $\mathrm{HDL}-\mathrm{C}$ in all group similar significant reduction in serum leptin levels among the studied groups $(P<0.0001)$. However, there were no significant correlations between the response of leptin to exercise training (expressed as percent reduction from the baseline ) with the associated responses to exercise in any of the lipid profile parameters in all groups. In conclusion, high intensity aerobic exercise training could improve lipid parameters associated with reduction of serum leptin concentration. However, this exercise-induced leptin reduction may restore leptin sensitivity that might regulate metabolic adaptation to exercise.
\end{abstract}

\section{INTRODUCTION}

$$
\text { The }
$$$$
\text { notion }
$$

that

hypercholesterolemic individuals can lower their risk of heart disease and atherosclerosis by adopting strategies including diet and exercise to normalize blood lipid profiles has gained widespread acceptance ${ }^{(\mathbf{1})}$. Endurance trained athletes exhibit an anti- atherogenic lipid profile compared with their untrained cohort 
that is characterized by elevated high density lipoprotein cholesterol (HDLC) combined with lower triglycerides (TG) concentrations ${ }^{(2)}$. Total cholesterol (TC) and low density lipoprotein cholesterol (LDL-C) concentrations may be lower in trained athletes as well, ${ }^{(3)}$ although this finding is not universal. ${ }^{(4)}$ Furthermore, in previously sedentary individuals, sufficient amount of exercise training is often, but not invariably, accompanied by an increase in HDL-C and a decrease in TG concentrations ${ }^{(\mathbf{5 , 6})}$. However, these findings are not beyond dispute. Davis et al. ${ }^{(7)}$ did not find significant changes in lipids or apolipoprotein concentrations in trained men after 60 and 90 minutes of exercise. When lipid changes have been reported to occur after exercise, the time of onset and the temporal decay of the response varies widely. Also, it is not clear whether regular exercise training or a single session of exercise will exert changes in lipid profiles of hypercholesterolemic individuals comparable to those occuring in their normocholesterolemic counterparts. So, the controlled clinical study in lipid pattern in response to programmed acute and chronic exercise training in untrained persons is more likely to be relevant to evalute exercise effect on the risk of coronary heart disease. ${ }^{(1)}$

The possible mechanisms by which exercise could directly modify lipid metabolism have been widely studied. Leptin, a liporegulatory hormone, may control lipid homeostasis in $\operatorname{adipose}^{(8)}$ and nonadipose $^{(9)}$ tissues unrelated to body weight control. When adipocytes store excess calories as triacylglycerol; leptin secretion rises to prevent accumulation of lipids in non adipose tissues which are not adapted to triacylglycerol storage. ${ }^{(\mathbf{1 0})}$ Neverthless, the relations between serum leptin concentration, serum lipids and lipoprotein are not yet clear. Further, regulation of lipolysis by exercise, possibly via increased plasma free fatty acids and glycerol levels, ${ }^{(11)}$ could be potentially relevant to regulation of circulating leptin levels as lipolysis and leptin production appear to be inversly controlled. $^{(12)}$ However, results regarding the effects of exercise on plasma leptin concentrations, independent on fat mass, are conflicting. Although several investigators have not found an acute effect of exercise on circulating leptin, ${ }^{(13,14)}$ others have reported a reduction in plasma leptin after short $^{(15)}$ and prolonged $^{(16)}$ term exercise which is independent on changes in body weight and plasma insulin. Furthermore, the relationship between post-exercise related changes in leptin with concomittent changes in plasma lipids is yet to be determined.

The aim of the present work is to investigate the effect of acute and chronic exercise on plasma lipids in obese and nonobese sedentary hyperlipidemic patients, in relation to circulating levels of leptin.

\section{SUBJECTS \& METHODS}

This study was performed in Clinical Physiology and Applied Medical Chemistry Department in Medical Research Institute, Alexandria University. Fourty non 
smokers and unmedicated volunteers with blood pressure $<140 / 90$ were enrolled into this study. All subjects were essentially sedentary and did not exercise regularly for at least four weeks. No subject had evidence of a significant coronary disease based on history, examination and exercise electrocardiogram. All subjects included in the study were informed about the purpose of the study and gave their informed consents to participate. They refrained from any strenuous exercise for 24 hours before the experiments and they were instructed to maintain their habitual diets The subjects $(n=40)$ were categorized according to World Health Organization (WHO) ${ }^{(17)}$ and National Cholestrol Education Program (NCEP) ${ }^{(18)}$ into four groups, ten in each:

- Group I included non-obese subjects (5 females and 5 males) with body mass index from 18.5 to $\leq 25 \mathrm{~kg} / \mathrm{m}^{2}$ and normal plasma lipid profile.

- Group II included obese subjects (3 females an 7 males) with body mass index $\geq 30 \mathrm{~kg} / \mathrm{m}^{2}$ and normal plasma lipids.

- Group III included lean patients (5 females and 5 females) with plasma hyperlipidemic profile (cholesterol $\geq 6.0 \mathrm{mmol} / \mathrm{L}$ and triglycerides $\geq 4$ $\mathrm{mmol} / \mathrm{L}$ ).

- Group IV included obese hyperlipidemic subjects (4 females and 6 males).

All subjects were investigated after 14 hours overnight fast and a venous blood sample was withdrawn for measurements of serum lipids and serum leptin concentrations before and immediately after a single session of exercise and after the end of exercise trainning program (twice weekly for 12 weeks).

Determination of plasma lipids: Total cholestrol (TC), triglycerides ( TG ) and high density lipoprotein (HDL-C) were analysed by means of commerical kits (Human, Weisbaden-German) using the GOP/PAP enzymatic colorimetric, CHOD/PAP enzymatic colorimetric, and direct CHOD/PAP enzymatic colorimetric methods respectively. Low density lipoprotein (LDL-C) is calculated from the primary measurements using the empirical equation. $^{(19)}$

Determination of leptin levels: Serum leptin levels were detected by Enzyme Linked Immunosorbant Assay ( ELISA ) kit for human leptin (DSL, Inc., Webster-USA) ${ }^{\mathbf{( 2 0 )}}$

Exercise protocol : This protocol was performed using an electrically braked cycle ergometer. ${ }^{(21)}$ The incremental exercise was done starting within warm up period at "0" watt for 2 minutes. The load was incremented automatically by 20 watt at 2 minutes interval till maximal tolerable work load, at which the individuals reach maximum heart rate, could be determined. Every subject performed supervised regular exercise training twice weekly for three monthes at the level of $85 \%$ of the predetermined maximal load for about 45 minuts in each setting..

\section{Statistical analysis}

All data are presented as mean values $\pm \mathrm{SD}$ and the response to exercise was assessed as percent change from baseline value. They were compared using Statistical Package for the Social Sciences 
(SPSS) computer program. Sudent $t$ test for paired values compared data before and after acute and chronic exercise in the same group. Paired $t$ test for unpaired values compared values among studied groups. Pearson's correlation coefficient " $r$ " was used to find out the relation between different parameters. $\mathrm{P}$ value was considered significant if $\leq 0.05$.

\section{RESULTS}

Table I demonstrated anthropometric data of studied groups. All groups were comparable as regard the mean age and height whereas obese groups (group II and IV) had statistically higher mean values of body weight $(\mathrm{p}<0.01)$ and BMI $(\mathrm{P}<0.01)$ than the control group. However the body weights and body mass indices did not change over the course of the entire study.

Table II showed that there was no significant difference between normolipidemic subjects (group I and II) as regard the serum lipid concentration (TC, TG, HDL-C, and LDL-C). In turn, all lipid profile parameters, apart from HDL-C, were significantly higher in hyperlipidemic subjects (group III and IV) than controls.

After single bouts of exercise, all groups demonstrated no significant changes in studied lipid profile parameters including TC, TG, HDLC, LDL-C and VLDL-C. (Table II). Also, endurance exercise training induced significant lowering effect on cholesterol in all groups including control $(p<0.001)$ and obese $(\mathrm{p}<0.0001)$ normolipidemic and lean $(p<0.0001)$ and obese $(p<0.0001)$ dyslipidemic subjects. Also, exercise training significantly decreased triglycerides in group I $(p<0.002)$, group II $(p<0.001)$, group III $(\mathrm{p}<0.003)$ and group IV $(\mathrm{p}<0.001)$ and also significantly reduced LDL-C levels in group I $(p<0.0001)$, group II $(p<0.001)$, group III $(p<0.01)$ and group IV $(p<0.0001)$. In turn, this exercise program caused significant elevation in HDL-C in normolipidemic obese $(p<0.05)$ and hyperlipidemic lean $(\mathrm{p}<001)$ and obese subjects $(p<0.05)$, meanwhile VLDL-C demonstrated significant reduction in group I $(p<0.05)$, group II $(p<0.001)$, group III $(p<0.0001)$, and group IV $(\mathrm{p}<0.001)$ after 12-week endurance exercise.

Table II also demonstrates that there was no significant effect of a single bout of exercise on the level of serum leptin concentration compared to pre-exercise values. In contrast, chronic exercise, twice weekly for 12 weeks, induced significant reduction in serum leptin concentration in normolipidemic lean $(\mathrm{p}<001)$ and obese $(p<0.0001) \quad$ subjects and dyslipidemic lean $(\mathrm{p}<0.001)$ and obese $(p<0.001) \quad$ subjects compared with their basal values.

Table III shows that serum leptin levels were significantly higher in normalipidemic obese subjects $(\mathrm{p}<$ $0.0001)$ and obese $(p<0.0001)$ and non obese $\quad(p<0.0001) \quad$ hyperlpidemic groups compared with the leptin level in lean normolipidemic control group. There were no significant correlations between basal serum leptin levels with any basal serum lipid profile parameters in the four studied groups.

Figure 1 shows the post-exercise training responses (expressed as 
percentage from the baseline) of the studied lipid parameters among all groups. The response of all lipid profiles were comparable in normolipidemic lean and obese groups. The highest responses were demonstared among the lean hyperlipidemic groups concerning the percent change after exercise training in TC $(\mathrm{p}<0.01$ and $<0.01)$, TG $(\mathrm{p}<0.01$ and $<0.01)$ HDL-C $(\mathrm{p}<0.05$ and $<0.05)$ and VLDL-C $(\mathrm{p}<0.05$ and $<0.001)$ compared to responeses to this exercise training in both normolipidemic groups and obese dyslipidemic group respectively.

Figure 1 also demonstrated that there were no significant differences in responses of leptin to exercise training (assessed by percent reduction from the basal values) among studied groups. Moreover, there was no significant correlations between the post-exercise percent reduction in leptin level and the degree of post-exercise changes in any of the measured lipid patterns in the four studied groups after long term exercise.

Table (1): clinical characteristics of the studied groups

\begin{tabular}{|l|l|l|l|l|}
\hline & \multicolumn{1}{|c|}{$\begin{array}{c}\text { Group I } \\
\text { Lean } \\
\text { Normolipidemic }\end{array}$} & $\begin{array}{c}\text { Group II } \\
\text { Obese } \\
\text { Normolipidemic }\end{array}$ & $\begin{array}{c}\text { Group III } \\
\text { Lean } \\
\text { Dyslipidemic }\end{array}$ & $\begin{array}{c}\text { Group IV } \\
\text { Obese } \\
\text { Dyslipidemic }\end{array}$ \\
\hline Age, yr & $33 \pm 10.31$ & $35.3 \pm 8.50$ & $41.05 \pm 8.70$ & $44,25 \pm 7.77$ \\
\hline sex, F/M & $5 / 5$ & $3 / 7$ & $5 / 5$ & $4 / 6$ \\
\hline Height, cm & $180.6 \pm 8.11$ & $176.3 \pm 8.06$ & $177.7 \pm 7.49$ & $166.2 \pm 5.76$ \\
\hline Weight, kg & & & & \\
\hline Before exercise & $80.30 \pm 0.18$ & $107.35 \pm 8.86^{*}$ & $76.59 \pm 10.88$ & $98.6 \pm 4.67^{*}$ \\
\hline After acute exercise & $80.30 \pm 0.17$ & $107.35 \pm 8.86^{*}$ & $76.55 \pm 10.91$ & $98.6 \pm 4.67^{*}$ \\
\hline After chornic exercise & $80.21 \pm 0.13$ & $107.35 \pm 8.86^{*}$ & $76.35 \pm 10.83$ & $98.6 \pm 4.67^{*}$ \\
\hline BMI, kg/m ${ }^{2}$ & $24.37 \pm 0.88$ & $34.43 \pm 5.55^{*}$ & $24.06 \pm 14.3$ & $34.53 \pm 1.84^{*}$ \\
\hline
\end{tabular}


Table (II): Serum lipid profile parameters before and after acute and chronic exercise intervention in all studied groups

\begin{tabular}{|c|c|c|c|c|c|c|}
\hline $\begin{array}{l}\text { Lipid } \\
\text { parameters }\end{array}$ & Groups & $\mathbf{A}$ & B & $\mathbf{C}$ & $\mathbf{P}$ & $\mathbf{P}^{\phi}$ \\
\hline \multirow{4}{*}{$\begin{array}{l}\text { Cholesterol } \\
(\mathrm{mmol} / \mathrm{L})\end{array}$} & Group I & $5.13 \pm 0.41$ & $4.98 \pm 0.38$ & $4.34 \pm 0.64$ & NS & $<0.001$ \\
\hline & Group II & $5.66 \pm 0.48$ & $5.21 \pm 0.45$ & $4.78 \pm 0.31$ & NS & $<0.0001$ \\
\hline & Group III & $7.37 \pm 1.28^{* *}$ & $7.39 \pm 0.82$ & $5.38 \pm 0.55$ & NS & $<0.0001$ \\
\hline & Group IV & $6.96 \pm 0.69^{* *}$ & $6.83 \pm 0.47$ & $5.89 \pm 0.44$ & NS & $<0.0001$ \\
\hline \multirow{4}{*}{$\begin{array}{l}\text { Triglycerides } \\
(\mathrm{mmol} / \mathrm{L})\end{array}$} & Group I & $1.47 \pm 0.38$ & $1.45 \pm 0.43$ & $1.23 \pm 0.40$ & NS & $<0.002$ \\
\hline & Group II & $1.93 \pm 0.49$ & $1.83 \pm 0.30$ & $1.51 \pm 0.39$ & NS & $<0.0001$ \\
\hline & Group III & $2.62 \pm 1.26^{*}$ & $2.41 \pm 0.94$ & $1.33 \pm 0.45$ & NS & $<0.003$ \\
\hline & Group IV & $2.25 \pm 0.63 * *$ & $2.17 \pm 0.59$ & $1.91 \pm 0.58$ & NS & $<0.001$ \\
\hline \multirow{4}{*}{$\begin{array}{l}\text { High-density } \\
\text { lipoprotein- } \\
\text { cholestrol } \\
(\mathrm{mmol} / \mathrm{L})\end{array}$} & Group I & $0.95 \pm 0.09$ & $0.96 \pm 0.07$ & $0.99 \pm 0.08$ & NS & NS \\
\hline & Group II & $1.04 \pm 0.24$ & $1.04 \pm 0.21$ & $1.09 \pm 0.26$ & NS & $<0.05$ \\
\hline & Group III & $0.93 \pm 0.18$ & $0.93 \pm 0.15$ & $1.30 \pm 0.39$ & NS & $<0.01$ \\
\hline & Group IV & $1.10 \pm 0.18$ & $1.09 \pm 0.19$ & $1.19 \pm 0.19$ & NS & $<0.05$ \\
\hline \multirow{4}{*}{$\begin{array}{l}\text { low-density } \\
\text { lipoprotein- } \\
\text { cholestrol } \\
(\mathrm{mmol} / \mathrm{L})\end{array}$} & Group I & $3.51 \pm 0.38$ & $3.20 \pm 0.56$ & $2.79 \pm 0.57$ & NS & $<0.001$ \\
\hline & Group II & $3.67 \pm 0.55$ & $3.60 \pm 0.59$ & $2.99 \pm 0.34$ & NS & $<0.01$ \\
\hline & Group III & $5.23 \pm 1.44 * *$ & $4.99 \pm 1.20$ & $4.02 \pm 0.79$ & NS & $<0.01$ \\
\hline & Group IV & $4.83 \pm 0.75^{* *}$ & $4.65 \pm 0.62$ & $3.88 \pm 0.45$ & NS & $<0.0001$ \\
\hline \multirow{4}{*}{$\begin{array}{l}\text { Very low-density } \\
\text { lipoprotein- } \\
\text { cholestrol } \\
(\mathrm{mmol} / \mathrm{L})\end{array}$} & Group I & $0.67 \pm 0.17$ & $0.63 \pm 0.19$ & $0.51 \pm 0.15$ & NS & $<0.05$ \\
\hline & Group II & $0.87 \pm 0.22$ & $0.81 \pm 0.19$ & $0.68 \pm 0.17$ & NS & $<0.0001$ \\
\hline & Group III & $1.18 \pm 0.56^{*}$ & $1.12 \pm 0.48$ & $0.71 \pm 0.34$ & NS & $<0.000$ \\
\hline & Group IV & $1.01 \pm 0.29 * *$ & $0.98 \pm 0.24$ & $0.80 \pm 0.21$ & NS & $<0.001$ \\
\hline \multicolumn{7}{|c|}{$\begin{array}{l}\text { Group I: Lean normolipidemics } \\
\text { Group III: Lean dyslipidemics }\end{array}$} \\
\hline $\begin{array}{l}\mathrm{P}: \text { is determine } \\
\mathrm{p}^{\phi}: \text { is determine } \\
*^{*} \mathrm{p}:<0.05 \text { comp } \\
* * \mathrm{p}: \quad<0.01 \text { comp }\end{array}$ & $\begin{array}{l}\text { by student tes } \\
\text { by student " } t \text { " } \\
\text { ed with lean } n\end{array}$ & $\begin{array}{l}\text { for paired value } \\
\text { est for paired va } \\
\text { rmolipidemic g }\end{array}$ & $\begin{array}{l}\text { o compare be } \\
\text { es to compare } \\
\text { up I using stuc }\end{array}$ & $\begin{array}{l}\text { re and after si } \\
\text { asal and post } \\
\text { nt "t" test for }\end{array}$ & $\begin{array}{l}\text { gle ex } \\
\text { raining } \\
\text { inpaire }\end{array}$ & $\begin{array}{l}\text { rcise values } \\
\text { values. } \\
\text { values. }\end{array}$ \\
\hline
\end{tabular}


Table (1II): Serum leptin levels (ng/ml) before and after acute and chronic exercise intervention in all studied groups.

\begin{tabular}{|l|l|l|l|l|l|}
\hline & $\begin{array}{l}\text { Before } \\
\text { exercise }\end{array}$ & $\begin{array}{l}\text { Acute } \\
\text { exercise }\end{array}$ & $\begin{array}{l}\text { Chronic } \\
\text { exercise }\end{array}$ & p & $\mathbf{p}^{\phi}$ \\
\hline $\begin{array}{l}\text { Group I } \\
\text { Lean } \\
\text { Normolipidemic }\end{array}$ & $10.33 \pm 2.51$ & $8.99 \pm 2.5$ & $5.05 \pm 2.48$ & NS & $<0.0001$ \\
\hline $\begin{array}{l}\text { Group I } \\
\text { Lean } \\
\text { Normolipidemic }\end{array}$ & $20.47 \pm 7.61^{* *}$ & $17.92 \pm 8.35$ & $12.34 \pm 6.87$ & NS & $<0.0001$ \\
\hline $\begin{array}{l}\text { Group I } \\
\text { Lean } \\
\text { Normolipidemic }\end{array}$ & $28.20 \pm 15.19^{*}$ & $22.59 \pm 9.49$ & $15.17 \pm 7.16$ & NS & $<0.0001$ \\
\hline $\begin{array}{l}\text { Group I } \\
\text { Lean } \\
\text { Normolipidemic }\end{array}$ & $27.40 \pm 5.11^{* *}$ & $26.00 \pm 4.83$ & $14.05 \pm 2.89$ & NS & $<0.0001$ \\
\hline
\end{tabular}

Values are means \pm SD

$\mathrm{n}=10$ for all groups

Group I: Lean normolipidemics

Group II: Obese normolipidemics

Group III: Lean dyslipidemics

Group IV:Obese dyslipidemics

$\mathrm{P} \quad$ : is determined by student test for paired values to compare before and after single exercise values.

$\mathrm{p}^{\phi}$ : is determined by student " $\mathrm{t}$ " test for paired values to compare basal and post training values.

$* p:<0.05$ compared with lean normolipidemic group I using student " $t$ " test for unpaired values.

**p: $<0.01$ compared with lean normolipidemic group I using student " $\mathrm{t}$ " test for unpaired values. 


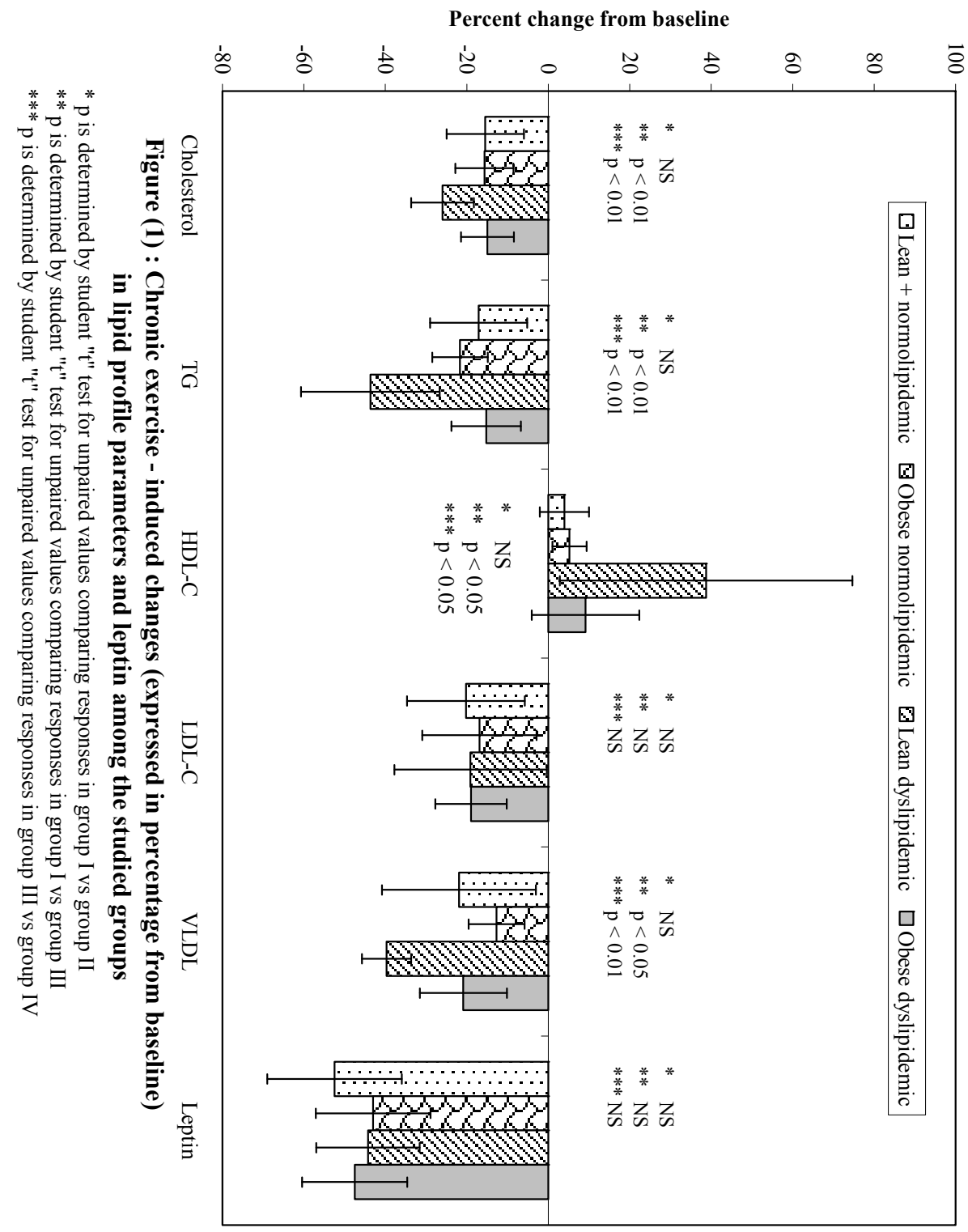




\section{DISCUSSION}

In the present study, serum leptin levels were significantly increased not only in obese groups but also in lean hyperlipidemic subjects compared with control subjects. No significant relations were found between serum leptin level and the levels of serum TC, LDL-C, VLDL-C, HDL-C or TG neither in the combined hyperlipidemic groups nor in the controls. High intensity endurance training exercise induced significant decreases in TC, TG, LDL-C and VLDL-C as well as increase in HDL$\mathrm{C}$ associated with concurrent significant decrease in serum leptin concentration in obese and non-obese hyperlipidemic subjects, a finding that was independent of changes in body weight.

Leptin, an adipocyte derived hormone, plays an important role in an energy homeostasis by signaling the brain about the amount of adipose tissue stored in the body. ${ }^{(8)}$ In our data, the concomitant increased leptin level with dyslipidemic state in obese and lean groups support the notion that leptin seems to be associated with other markers of the metabolic syndromes such as hyperlipidemia independently of changes in adiposity. The relationship between serum leptin concentration and serum lipids and lipoproteins are not clear. It has been revealed that an acute and substantial fall in plasma lipid concentration occurred in ob/ob mice, but not in $\mathrm{db} / \mathrm{ob}$ mice, when treated with even low dose of leptin that does not affect food intake or body weight. ${ }^{(22)}$ In turn, Wang et al. ${ }^{(23)}$ have shown that in normal adipocytes, leptin directly stimulates a novel form of lipolysis in which glycerol is released without a proportional release of FFA. By the use of conventional method, in which free glycerol is also counted as estrified glycerol, higher plasma triglyceride concentration was observed in transgenic skinny mice overexpressing leptin. Further, elevated leptin could produce leptinmediated antilipogenic protection, possibly through tissue specific modulation of LPL activities, permits TG stores to expand in adipocyte without over accumulation in nonadipose tissues. ${ }^{(\mathbf{1 0})}$ The association between hyperleptinemia and hyperlipidemia in our lean dyslipidemic subjects ${ }^{(24)}$ could represent a state of 'leptin resistance' similar to that occurred in obese subjects. Triglycerides are important causes of this leptin resistance as mediated by impaired transport across the BBB. ${ }^{(25)}$ Leptin promote triglyceride hydrolysis and FFA oxidation and inhibit FFA synthesis, therefore decreasing triglyceride level. In the absence of leptin activity, FA delivery to non adipose tissues may exceed oxidative requirements. Unoxidized FA excess may then enter deleterious metabolic pathway such as ceramide formation, lipid peroixdation, detergent action and increased omega oxidation. ${ }^{(2)}$ However, the ability of triglycerides to inhibit leptin transport into the brain completes a negative feedback loop between leptin action and triglycerides. ${ }^{(25)}$

Our observations were consistent with other in vivo and in vitro studies $^{(9,26,27,28)}$ that reported the association between plasma leptin with lipids and lipoprotein profile. 
However, most of the information available on leptin-induced changes in lipid metabolism has been obtained in vitro and the difference in lipid metabolism between rodent and human makes the comparison more complicated.

After single session of exercise, there were no significant changes in neither plasma lipids nor serum leptin in all groups. In accordance with our data, it was recorded that raising exercise intensity from $25 \%$ to $65 \%$ of maximal oxygen consumption $\left(\mathrm{VO}_{2 \max }\right)$ appeared to increase lipolysis in association with increasing plasma epinephrine concentration. When exercise intensity increases from 65 to $85 \% \mathrm{VO}_{2-\max }$, lipolysis plateaus despite further large increase in plasma epinephrine concentration. ${ }^{(29)}$ The increasing level of plasma insulin with the graded epinephrine concentrations may have modulated the full effect of epinephrine-stimulated lipolysis. ${ }^{(30)}$ In contrast, results presented in previous studies found that increased LPLA and HDL-C and decreased TC concentration 24-48 hours after prolonged exercise at $75 \%$ but not at $60 \%$ of $\mathrm{VO}_{2 \text {-max }}$ in studies in both trained and untrained individuals. ${ }^{(31)}$ An explanation for these inconsistencies may be related to one or more factors that include the use of different exercise protocols regarding the intensities and durations, different subject training status, different baseline lipoprotein values and possible post-exercise delayed changes in lipid concentrations.

On the other hand, the absence of significant change in serum leptin in short term exercise study may be due to the limited energy expenditure that reported to upregulate and downregulate leptin expression. ${ }^{(32)}$ Also, the reported diurnal rhythm of leptin concentration that depended on energy or carbohydrate availability and did not affect 24 hour leptin concentration $^{(33)}$ is more likely to be beyond acute exercise-related effect in our data.

Standardized exercise training program displayed favorable significant changes in the lipid profile, associated with significant decrease in serum leptin concentration in our combined hyperlipidemic subjects (lean and obese). The potential mechanism for increased HDL-C concentration may be increased LPLA. LPL is involved with TG degradation, providing substance material for HDL-C production and is known to be metabolically active several hours after exercise cessation.. A second potential mechanism for our finding of increased HDL-C concentration may decreased cholesterol ester transport protein (CETP) activity that facilitate transfer of cholesterol ester and triglycerides between HDL and other lipoprotein (HDL-C and LDL-C). ${ }^{(34)}$ In addition, hepatic lipase activity that involved in HDL-C metabolism was decreased immediately after exercise in most of exercise protocols. ${ }^{(35)}$ Many studies have shown that moderate intensity to high intensity exercise training $(>60 \%$ $\mathrm{VO}_{2 \text {-max }}$ ) could alter lipolytic response to beta-adrenergic stimuli with increased total fat oxidation during exercise in lean and obese subjects. ${ }^{(29)}$ Further, acute bout of exercise whether performed in the untrained or the trained state, did not significantly 
alter the expression of gene involved in FA uptake and metabolism $\left.\left(\mathrm{FAT} \mathrm{CD}_{36}\right), \mathrm{FABP}_{\mathrm{PM}}, \mathrm{CTP}_{1}, \beta-\mathrm{HAD}\right)$ or transcription factors measured immediately at the cession of exercise or 3 hours post-exercise. In contrast, exercise training increased FA oxidation during exercise, yet this was accompanied by an increase in the expression of just two of the selected genes $\left(\mathrm{FAT} / \mathrm{CP}_{36}\right.$ and $\left.\mathrm{CPT}_{\mathrm{I}}\right){ }^{(\mathbf{( 3 6})}$

In our data, post-exercise improvement in lipid patterns in obese subjects was significantly lower than the corresponding improvement in lean subjects. However, obese subjects are known to have low activity of enzymes of $\beta$-oxidation, low skeletal muscle lipoprotein lipase and impaired mobilization of fat stores. The dysregulation of FA metabolism associated with hyperleptinemia is strongly implicated with the development of insulin resistance where antilipolytic effect of insulin is reduced. $^{(37)}$

The absence of correlations between post exercise response of plasma lipids and serum leptin changes may have instead been caused by some of the concomitant metabolic interaction between leptin and other hormones such as insulin, catecholamines that influence $\mathrm{TG}$ turnover or fatty acid metabolism. Epinephrine or epinephrine-induced hormonal changes decreased leptin mRNA and plasma leptin in healthy men. ${ }^{(38)}$ Insulin-stimulated leptin secretion could be inhibited by exercise-induced catecholamine and other lipolytic hormones. ${ }^{(39)}$ Other mechanisms such as the influence of exercise on expression of intrleukin- 6 $(\mathrm{IL}-6)^{\mathbf{( 3 8 )}}$ and tumor necrosis factor- $\alpha$
$(\mathrm{TNF}-\alpha)^{(\mathbf{1 1})}$ in adipocytes and muscle cells have to be considered. Both leptin and TNF- $\alpha$ are directly related and regulated by the same mechanism, the peroxisome proliferator-activated receptor family, which is also important for fatty acid metabolism and insulin sensitivity. ${ }^{(11)}$

Numerous studies have concluded that moderate exercise training has little effect on lipid profile and leptin concentration unless combined with weight loss or change in dietary quality. ${ }^{(33,39,40)}$ However, difference between initial concentration of lipids and status of hyperleptinemia could affect the results.

Leptin reduction associated with endurance training in our study could reflect a state of improved leptin sensitivity in obese and lean hyperlipidemic subjects that might be related to concomitant post-exercise reduction of triglycerides. Exerciseinduced fall of leptin could play a central role in regulating the neuroendocrine adaptation to exercise including the hypothalamic-pituitarygonadal axis and, in part, the hypothalamic-pituitary-thyroid axis and IGF-1 binding capacity in serum. ${ }^{(41)}$ However, similar adaptive neuroendocrine and metabolic response to leptin reduction induced by alternations in nutritional state were reported in experimental protocols. ${ }^{(\mathbf{4 2})}$ So, it is tempting to speculate that exercise-related leptin signaling reduction could restore a regulatory feed back loop where leptin acts within the hypothalamus to cause activation of central sympathetic outflow and stimulation of adrenal medullary release of epinephrine and conversely, the sympathetic nervous system 
activity promotes downregulation of leptin release from adipose tissue. ${ }^{(43)}$

In conclusion, this study has shown that hyperlipidemic subjects, obese and non obese, demonstrated higher basal level of serum leptin. A single session of exercise has no acute effects on lipid profile or leptin concentration, In turn, chronic endurance exercise training induced concurrent significant reduction in both serum lipid profile and leptin concentration. These results reinforce the notion that combined hyperlipidemia was associated with a leptin resistance status, independent of body mass index. However, exercise training, that decrease leptin levels, may restore leptin sensitivity that might regulate the metabolic adaptation to exercise.

\section{REFERENCES}

1. Fontana L, Vilareal DT, Weiss EP, Racette SB, Steger-May K, Klein S, and Holloszy JO. Caloric restriction or exercise: Effects on coronary, heart disease risk factors. A randomized controlled trial. Am J Physiol Endocrinol Metab 2007;0 :00102.2007v1 (in press).

2. Couillard C, Despres JP, Lamarche B, Bergeron J, Gagnon J, Leon AS, Rao DC, Skinner JS, Wilmore JH, Bouchard C. Effects of endurance exercise training on plasma HDL cholesterol levels depend on levels of triglycerides: evidence for men of the Health, Risk Factors, Exercise Training and Genetic (HERIATAGE) family study. Arterioscler
Thromb Vasc Biol 2001; 21(7): 1226-32.

3. Durstine JL, Haskell WL. Effect of exercise training on plasma lipids and lipoproteins. Exercise Sport Sci Rev 1994; 22: 477-521.

4. Zmuda JM, Yurgalevitch SM, Flynn MM, Bausserman LL, Saratelli A, Spannaus-Martin DJ, Herbert PN, Thompson PD. Exercise training has little effect on HDL levels and metabolism in men with initially low HDL cholesterol. Atherosclerosis 1998; 137(1): 215-21.

5. Gordon PM, Goss FL, Visich PS, Warty V, Denys BJ, Metz KF, Robertson RJ. The acute effect of exercise intensity on HDL-C metabolism. Med Sci Sports Exerc 1994; 26: 671-7.

6. Thompson PD and Rader DJ. Does exercise increase HDL cholesterol in those who need it the most. Arterioscl Thromb Vasc Biol 2001; 21: 1097- 8 .

7. Davis PG, Bartoli WP, Durstine JL. Effects of acute exercise intensity on plasma lipids and apolipoproteins in trained runners. J Appl Physiol 1992; 72: 914-9.

8. Park BH, Wang MY, Lee Y, Yu $X$, Ravazzola $M$, Orci $L$ and Unger RH. Combined leptin actions on adipose tissue and hypothalamus are required to deplete adipocyte fat in lean rats. J Biol chem. 2006; 52: 40283-91.

9. Dube JJ, Bhatt BA, Dedousis N, Bonea A, and O'Doherty RM. Leptin, skeletal muscle lipids and lipid-induced insulin resistance. Am J Physiol Regul Integr Comp 
Physiol 2007;0:00133.2007v1.(In press ).

10. Unger RH. Hyperleptinemia: Protecting the heart from lipid overload. Hypertension 2005; 45(6): 1031-4.

11. Berggren JR, Hulver MW and Houmard JA. Fat as an endocrine organ: influence of exercise. J Appl Physiol 2005; 99: 757-764.

12. Fisher JS, Van Pelt RE, Zinder O, Landt M, Kohrt WM. Acute exercise effect on post absorptive serum leptin. J Appl Physiol 2001; 91: 680-6.

13. Kreamer RR, Chu H, Castracane VD. Leptin and exercise. Exp Biol Med 2002; 227(9): 701-9.

14. Zafeiridis A, Smilios I, Considine RV, Tokmakidis SP. Serum leptin responses after acute resistance exercise protocols. J Appl Physiol 2003; 94(2): 591-7.

15. Jürimāe $J$ and Jürimāe $T$. Leptin responses to short term exercise in college level male rowers. Br J Sports Med 2005; 39: 6-9.

16. Fatouros IG, Tournis $S$, Leontsini DL, Jamurtas AZ, Sxina M, Thomakos P, Manouski M, Douroudos I, Toxidaris K, and Mitrakou A. Leptin and adiponectin responses in overweight inactive elderly following resistance training and detraining are intensity related. J Clin Endocrinol and Metab 2005; 90: 5970-5977.

17. WHO. Obesity: preventing and managing the global epidemic. Report of a WHO Consultation.
WHO Technical Rport Series 894. Geneva: World Health Organization, 2000.

18. Excutive summary of the third report of the National Cholesterol Education Program (NCEP) Expert Panel on Detection, Evaluation and Treatment of High blood cholesterol in adults (Adult Treatment Panel III). JAMA 2001; 285(19): 2486-249

19. Considine RV, Sinha MK, Heiman ML, Kirauciunas A, Stephenus TJ, Nycce MR, Ohannesian JR, Marco CC, McKee IJ, Bauer TL, Caro JF. Serum immunoreactive-leptin concentration in normal weight and obese humans. N Engl J Med 1996; 334: 292-5.

20. American Thoracic Society/American College of chest physicians. ATS/ACCP statement on cardio-pulmonary exercise testing. Am J Respir Crit Care Med 2003; 167: 211-77.

21. Reidy SP and Weber J. Acclerated substrate cycling: a new energy-wasting role for leptin in vivo. Am J Physiol Endocrin Metab 2002; 282: E312-E317.

22. Wang MY, Lee $Y$ and Unger RL. Normal form of lipolysis induced by leptin. J Biol Chem 1999; 274: 17541-17544.

23. Thong FSL, Hudson R, Ross R, Janssen I and Graham TE. Plasma leptin in moderately obese men: independent effects of weight loss and aerobic exercise. Am J Physiol Endocrinol Metab 2000; 279: E307-E313. 
24. Banks WA, Coon AB, Robinson SM, Moinuddin A, Shultz JM, Nakaoke $\mathbf{R}$ and Morley JE. Triglycerides induce leptin resistance at the blood-brain barrier. Diabetes 2004; 53: 125360.

25. Huang W, Dedousis $N$, Bandi A, Lopaschuk GD and Robert M. Liver triglyceride secretion and lipid oxidative metabolism are rapidly altered by leptin in vivo. Endocrinology 2006; 147: 1480-1487.

26. Der-Min W, Muh-Han $S$ and Nain-Feng C. Relationship between plasma leptin levels and lipid profile among school children in Taiwan-The Taipei Children Heart Study. Europ J Epidem 2001; 17: 911-916.

27. Tamer L, Ercan B, Unlu A, Sucu N, Pekdemir H, Eskandria $G$ and Atik U. The relationship between leptin and lipids in atherosclerosis. Indian Heart J 2002; 54: 692-6.

28. Mora-Rodriquez $P$ and Coyle EF. Effect of plasma epinephrine on fat metabolism during exercise: interactions with exercise intensity. Am J Physiol Endocrinol Metab 2000; 278: E669-E676.

29. Goto K, Ishii N, Mizuno $A$ and Takatsu K. Enhancement of fat metabolism by repeated bouts of moderate endurance exercise. J Appl Physiol 2007;

30. Ferguson MA, Alderson NL, Trost SG, Essig DA, Burke JR and Durstine JL. Effect of four different single exercise sessions on lipid, lipoproteins and lipoprotein lipase. J Appl Physiol 1998; 85: 1169-1174.

31. Franks PW, Loos RJF, Brage S, O'Rahilly S, Narcham NJ and Ekelund U. Physical activity energy expenditure may mediate the relationship between plasma leptin levels and worsening insulin resistance independently of adiposity. J Appl Physiol 2007; 102: 1921-1926.

32. Hilton LK and Loucks AB. Low energy availability, not exercise stress, suppresses the diurnal rhythm of leptin in healthy young women. Am J Physiol Endocrinol Metab 2000; 278: E43-E49.

33. Garen $C$, Perusse L, Bergeron J, Gagnon J, Chagnon YC, Borecki IB, Leon AS, Skinner JS, Wilmore JH, Roo DC and Bouchard C. Evidence of LPL gene-exercise interaction for body fat and LPL activity: the HERITAGE family study. J Appl Physiol 2001; 91: 1334-40.

34. Santamarina-Fojo S, GonzalezNavarro $H$, Freeman $H$, Wagner E and Nong Z. Hepatic Lipase, Lipoprotein Metabolism, and Atherogenesis. Arterioscler Thromb Vasc Biol 2004; 24(10): 1750-1754.

35. Tunstall RJ, Mehan KA, Wadley GD, Collier GR, Bonen $A$, Hargreaves $M$ and Cameron-Smith D. Exercise training increases lipid metabolism gene expression in human skeletal muscle. Am J Physiol Endocrinol Metab 2002; 283: E66-E72.

36. Frank LL, Sorensen BE, Yasui Y, Tworoger SS, Schwartz RS, Ulrich CM, Irwin ML, Rudolph 
RE, Rajan KB, Stanczyk F, Bowen D, Weigle DS, Potter JD and Mc Tiexnar A. Effect of exercise on metabolic risk variables in overweight post menopausal women: randomized clinical trail. Obesity Res 2005; 13: 615-625.

37. Keller P, Keller C, Steensberg $A$, Robinson LS and Pederson BK. Leptin gene expression and systemic levels in healthy men: effect of exercise, carbohydrate, interleuckin 6 and epinephrine. J appl Physiol 2005; 98: 18051812.

38. Reseland JE, Anderssen SA, Solvoll K, Hjermann I, Urdal P, Holme I and Drevon CA. Effect of long-term changes in diet and exercise on plasma leptin concentrations. Am J Clin Nutr 2001; 73: 240-5.

39. Van Aggel-Leijssen DPC, Saris WHM, Wagenmarkers AJM, Senden JM and Van Back
MA. Effect of exercise training at different intensities on fat metabolism of obese men. J Appl Physiol 2002; 92: 1300-9.

40. Chan JL, Heist K, DePaoli AM, Veldhuis JD and Mantzoros CS. The role of falling leptin levels in the neuroendocrine and metabolic adaptation to short term starvation in healthy men. $\mathrm{J}$ Clin Invest 2003; 111: 1409-21.

41. Steinberg GR, Smith AC, Wormald S, Malfant P, Collier $C$ and Dyck DJ. Endurance training partially reserves dietaryinduced leptin resistance in rodent skeletal muscle. Am J Physiol Endocrinol Metab 2004; 286: E57-E63.

42. Esler M, Straznicky N, Eikelis $N$, Masuo K, Lambert $G$ and Lambert E. Mechanism of sympathetic activation in obesityrelated hypertension. Hypertension 2006; 48: 787-796. 


\section{اثر المجهود البذنى على مستويات}

\section{هرمون اللبتين فى الام فى مرضى ارتفاع دهون الام}

أجرى هذا البحث لدراسة علاقة هرمون اللبتين بالمتغيرات فى مستويات دهون الدم المصاحبة للمجهود العضلى.

شمل البحث أربعون شخصاً لم بسبق لهم ممارسة الرياضة تم تقسيمهم إلى ؛ مجموعات

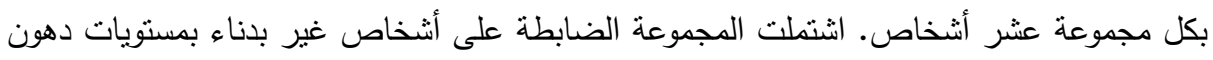
عادية بالدم والمجموعة الثانية على أثخاص بدناء بمستوى عادى فى دهون الدم والمجموعة الثالثة

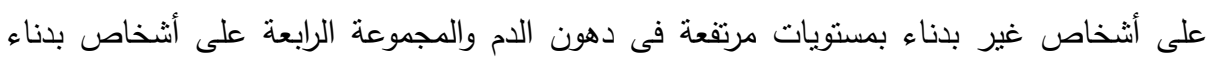
بمسنويات مرتفعة لدهون الدم.

تم قياس مستويات هرمون اللبتين ومستويات الكوليسترول والجلسيريدات الثلاثية والدهون منخفضة الكثافة والدهون عالية الكثافة قبل وبعد جلسة للمجهود العضلى وبعد الانتهاء من تكرار

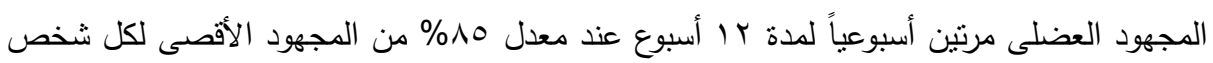

أظهرت النتائج ارتفاع مستوى هرمون اللبتين فى مجموعتى الأشخاص البدناء والمجموعة

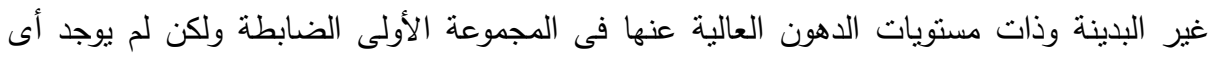

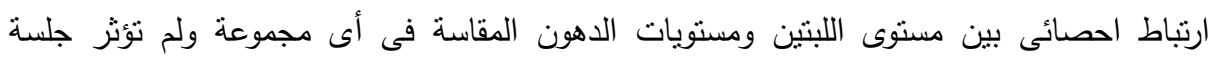

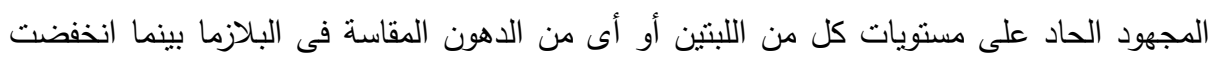

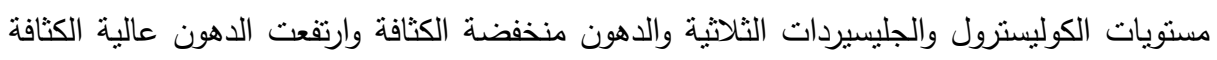

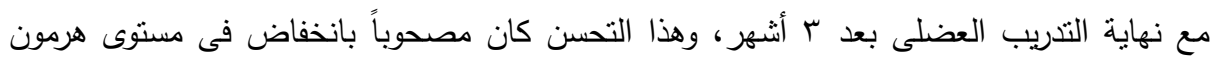

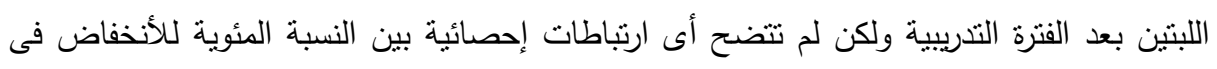

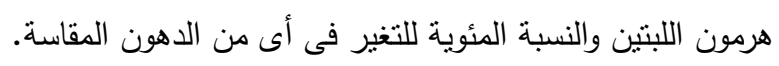

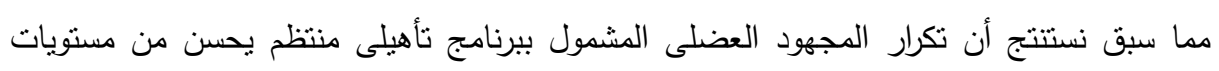

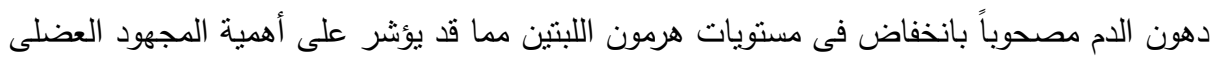
فى استعادة الحساسية لهرمون اللبتين فى تنظيم عمليات التحول الغذائى درئي 